Varsói Egyetem

\title{
Három magyar a Balti-tengernél
}

\section{A Balti-tenger és Gdańsk Somlyó György, Pethö Tibor és Ruffy Péter szemével}

A második világháború befejezése Magyarország és Lengyelország történetének új szakaszát nyitotta meg. Mindkét ország a Szovjetunió érdekszférájában találta magát, mindkét országban a hatalom fokozatosan, rövid idón belül, a demokrácia alapvetó

szabályait megszegve, a szovjetek támogatását élvezó helyi

kommunisták kezébe került; elkezdódött „a szocializmus épitésének" korszaka. Ez az 1989-ig tartó periódus a magyarlengyel kapcsolatok új fejezetét is jelentette. Attól eltekintve, hogy ezek a (hivatalos) kapcsolatok csak a meghatározott kereteken belül fejlödhettek, a két ország közötti kulturális együttmúködés

- ami különösen érdekes lehet a jelen tanulmányban tárgyalt problematika szempontjából - intenzív és gyümölcsözó volt. Ennek az egyik fontos megnyilvánulása a magyar írók és újságírók Lengyelország iránti széleskörú érdeklódése volt, ami például számos újságcikket és néhány figyelemre méltó útleírást, illetve riportkönyvet (riportgyújteményt) eredményezett; közöttük. található a tanulmány alapjául szolgáló három könyv is: A Visztula sellője. Lengyelországi útinapló Somlyó György tollából (1954), A Kárpátoktól a Balti-tengerig Pethó Tibortól ${ }^{2}$ (1956), valamint a Varsói hajnal Ruffy Pétertól ${ }^{3}$ (1961). ${ }^{4}$

1 Somlyó György (1920-2006) 1951-ben a Magyar Írószövetség költői szakosztályának titkára. 1953-54-ben irodalmi előadó az Országos Béketanácsnál. 1954-55-ben a Magyar Rádió Irodalmi Főosztályának vezetője. Számos verseskötet szerzője. (Somlyó György, Pethő Tibor és Ruffy Péter életrajza a bibliográfiában felsorolt források alapján készült el: Béládi és Rónai, 1990; Dávid, 2002; F. Almási, 2000; Zsoldos, 2019).

2 Pethő Tibor (1918-1996) újságíró, pályafutásának legfontosabb állomása a Magyar Nemzet (kétszer főszerkesztője is volt). A müvei közül említhető: Afrika és Délkelet-Ázsia népeinek szabadságharca (1952), Útikalandok a régi Magyarországon (társszerző, 1963), A háborúk ára (1966), Amerika közelröl (1972), Kölcsönben a jövö (1984).

3 Ruffy Péter (1914-1993) magyar újságíró és író volt. Az újságíró pályafutása során a Magyar Szó, Erdélyi Lapok, Brassói Lapok, Újság, Hírlap, Kis Újság, Béke és Szabadság, Érdekes Újság, végül (1959-től) a Magyar Nemzet belső, 1960-tól főmunkatársa volt. A második világháború utáni korszakban Ruffyt ,az ország újjáépítésének talán legfürgébb tollú tudósítójának” tekintették. Könyvei között gyüjteményes riportkötetek (Göcsejtöl Hegyaljáig, Romlás. Riportok a rumról, A reporter visszanéz, Úttalan utakon), útirajzok (Varsói hajnal, Szegedi képeskönyv, Hazánk szíve, Budapest), illetve történeti publicisztikai művek (Koronánk könyve) találhatók meg.

${ }^{4}$ A fentiekben felsoroltakon kívül 1945 és 1989 között a következő könyvek - az akkori Lengyelországról szóló útleírások vagy riportkönyvek (riportgyüjtemények) - jelentek meg: Barátok közt Lengyelhonban (Bodrogi Sándor és Ferkis Emil, 1964), Lengyelország (Pálos Tamás, 1964), Lengyel teakeverék (Sebők Éva, 1978), A Tátrától a tengerig. Lirai utazás Lengyelországban (Hajdók János, 1979), Varsói krónika 1979-1981 (Szilágyi Szabolcs, 1986). 
M ind a három említett útleírás ${ }^{5}$, a műfaji jellegéből adódóan, a szerzők azon lengyelországi utazásainak eredményeként született meg, amelyek során meglátogatták az ország legfontosabb városait, többek között Varsót, a fővárost, Krakkót, Wrocławot, valamint Gdańskot, a lengyel Balti-tengerpart legfontosabb városát is. A jelen tanulmány éppen a Balti-tengernek (elsősorban) és Gdańsknak Somlyó György, Pethő Tibor és Ruffy Péter által felrajzolt képére fókuszál. Kisebb mértékben, sajátos kiegészítésként, Gdynia képét tárgyalja ez a cikk, tekintettel arra, hogy Gdańsk e szomszéd várossal, valamint Sopot várossal együtt egy közös szervezetet, a Hármasváros nevü tengerparti városegyüttest alkotja.

Meg kell jegyezni, hogy Pethő Tibor és Ruffy Péter az útleírásukban különálló fejezetet szenteltek Gdańsknak (Pethőnél: Ahol a háború elkezdődött, Ruffynál: Az Ötfüttyöbölben), ezenkívül Pethő egy egész fejezetet Gdyniának és a Balti-tengernek is (,,Navigare necesse est”), Ruffy Varsói hajnaljában pedig a Balti-tenger és Gdańsk még néhány más fejezetben jelenik meg. Mind a két szerző riportszerüen rögzíti és közvetíti a magyar olvasó számára a tenger és Gdańsk (illetve Gdynia, Szczecin stb.) képét.

Pethő Tibor és Ruffy Péter lengyelországi útirajzának Gdańskot és a Balti-tengert illető narrációja jellegében különbözik a Somlyó Györgyétől: Somlyónál nincsenek hoszszabb riportszerü leírások, a szerző nem is alkot hosszabb, egybefüggő képet a tengerről, Gdańskról vagy például Gdyniáról. A Visztula sellőjének „tengerparti” részei irodalmi „mozaikkockáknak”, illetve irodalmi „képeslapoknak” nevezhetők (egyébként a szóban forgó útleírás egyik részének a címe éppen Tengerparti képeslapok), amelyekben maga a tenger, valamint Gdynia vagy Gdańsk látképének és életének a szerző által kiválasztott egyes „elemei” - mint például a kikötőbe beúszó halászbárka (Somlyó, 1954. 53-54.), a gdański kikötőben horgonyzó hajó fedélzetét mosó matróz (Somlyó, 1954. 52-53.) vagy „a híres aranytornyú gdanski városházában” található két festmény (Somlyó, 1954. 42-44.) - elsősorban filozófiai, politikai, történelmi elmélkedések kiindulópontját képezik. Somlyó tehát ezeken keresztül akar rámutatni egy-egy konkrét eseményre vagy általános jelenségre (a Gdynia kikötőjébe beúszó bárka látványa például a Daigo Fukuryu Maru japán halászhajó tragédiájának és a világbéke körüli elmélkedéseknek lesz az apropója, Anton Möller A templom épitése címü festménye pedig Gdańsk háborús elpusztítását és a háború utáni újjáépítését juttatja a szerző eszébe).

Mindhárom magyar szerző az 1950-es években járt Lengyelországban. Utazásaik szolgálati jellegüek voltak, nem turistákként, hanem újságírókként, riporterekként, a lengyel élet megfigyelőiként járták végig az országot. Somlyó György 1954 tavaszán volt Lengyelországban (április 4-től május 3-ig) (Somlyó, 1954. 81.). Pethő Tibor szintén tavasszal járt Lengyelországban, de egy évvel később, 1955-ben (április végén érkezett, és röviddel a híres varsói értekezlet befejezése után ${ }^{6}$, május 14-e után utazott el) (Pethő, 1956. 7., 239-246.). Ruffy Péter - ahogy maga írja a könyve befejező részében - 1945 és 1960 között négy ízben járt Lengyelországban (Ruffy, 1961. 191.), a Varsói hajnalban e négy utazásának „élményeit és tapasztalatait” (Tamás, 1961. 7.) foglalta össze.

Mind a három szerző Lengyelország-képe alapvetően két nagyobb dimenzióból tevődik össze: Somlyó, Pethő és Ruffy is egyrészt a háborús pusztítások, másrészt az ország újjáépítésének bemutatására törekednek útirajzaikban, s ez meghatározó szerepet tölt be a Balti-tenger és főleg Gdańsk képének közvetítésében is. Kérdés, hogy az akkori hivatalos történetírás és az uralkodó kommunista politikai propaganda mennyire befolyásolta

5 Nem merülve bele a müfaji megkülönböztetések és definiciók részleteibe, e tanulmányban a három felsorolt könyvre az „útleírás” (esetleg „útirajz”) műfaji terminussal utalunk.

${ }^{6}$ A Varsói Szerződést nyolc európai szocialista ország írta alá az 1955. május 14-én, Varsóban megtartott értékezlet utolsó napján. 
az írók ${ }^{7}$ látásmódját és az útleírások tartalmi oldalát. A jelen tanulmány részben e kérdésre is igyekszik választ adni.

\section{A Balti-tenger képe a három útleírásban}

A Balti-tengernek a szóban forgó útleírásokban megalkotott összképében ${ }^{8}$ alapvetően négy megközelítési szempont különíthető el. A Balti-tenger (természeti) szépségként, látványosságként és ezzel szoros összefüggésben hatalmas természeti erőként (1), romantikus (vagyis képzeletre és érzelmekre ható), szinte mágikus térségként (2), az „új”, Lengyelország és a lengyelek életének fontos elemeként, illetve az ember munkájának színhelyeként (3), valamint fontos történelmi események színtereként (4) jelenik meg. Ezek a szempontok nemritkán átszövik, illetve kiegészítik egymást.

Ami a Balti-tengert mint természeti szépséget, illetve természeti erőt illeti, Somlyó György és Pethő Tibor az útleírásukban költői tájképet festenek róla. Az utóbbi szerző a nyugtalan tenger látképét írja le:

A szél habzó, tarajos hullámokat kergetett a part felé. A Balti-tenger mennyire más, mint a lágy, sötétkék, mediterrán tengerek, félelmetesebb, szürkébb, fenyegetőbb. Lélegzik. Visszahúzódik a homokdünékröl, hogy aztán ismét elöntse azokat tíz-tizenkét méterre. Még ebben a ragyogó napsütésben sem csábítja fürdésre az embert. Hideg. Július, augusztus, ez a két hónap, amikor partjait ellepik a fürdőzők. Mégis, ez a tenger adja az életet itt, sok száz kilométer hosszúságában a falvak és városok lakóinak. (Pethö, 1956. 125.)

Somlyó György pedig az alkonyi tenger szelíd látványát jeleníti meg érzékletesen. Leírásában a Balti-tenger nem csupán a szó szoros értelmében vett természeti szépségként szerepel, mivel szó esik az emberi kéz „alkotásairól”, tudniillik a gdyniai kikötő „kőkarjairól” és egy bárkáról is:

A Köhegyen, a Kamienna Górán álltam, Gdynia kikötője felett az alkonyatban. A szinte mozdulatlannak tünő csendben, mint egyetlen szépséges dallam úszott be lassan a kikötő kőkarjai közé egy apró sárga bárka a kék tengeren, a színeknek abban a csodálatosan szelíd tisztaságában, amit csak a koranyári alkonyat fénye tud festeni. Elbűvölő volt az egész látvány egységes szépsége: a tág látóhatár, a tengerbe félkörben benyúló hatalmas kikötő s a picike bárka tökéletes harmóniája. (Somlyó, 1954. 53.)

Pethő lírai leírásában a „lengyel” tenger ,jellegzetességeire” mutat rá, arra tudniillik, hogy nyugtalan, hideg és a vize sötét színü; aggodalmat kelt a szemlélőben, egy kicsit dühös vadállatra hasonlít. Az idézett részletben a Balti-tenger a mediterrán tengerek ellentéteként jelenik meg. Nagy mértékben különbözik például az Adriától, amelynek - elsősorban történelmi és földrajzi okokból kifolyólag - a világ többi tengerével szemben kiemelt helye van a magyarok tudatában.

Mind a két fentebb idézett részlet kisebb irodalmi képeslapnak is felfogható, tömör, szavakkal festett (táj)képnek (Ćurković-Major, 2002. 79-80.). A harmonikus, nyugalmas

7 Pethő Tibor és Ruffy Péter elsősorban újságírók voltak, Somlyó György pedig költő. Némi leegyszerűsítéssel a jelen tanulmányban ,'́róknak”, illetve ,szerzőknek” fogjuk nevezni őket.

${ }^{8}$ A Balti-tenger összképe alatt e tengernek mindhárom útleírás mindegyikében megrajzolt képéből összeálló „nagyobb” képet értjük. 
Balti-tengernek Somlyó György által adott leírását azért is lehet „képeslapszerünek” tekinteni, mert egy olyan sztereotipikusan idilli (s bizonyos mértékig giccsesnek ható) tengeri jelenetet állít az olvasó tekintete elé, amely emlékeztet az átlagos tengerparti szuvenírboltokban kapható színes képeslapokra, festményekre vagy fényképekre. Ezek nélkülözhetetlen elemei voltak a sárga színü halászbárkák (sok évig a lengyel tengerparti tájkép állandó tartozékai), a kikötő és a tenger kéksége. ${ }^{9}$

Az útleírás e részének narrációjában ez az idillikus kép nemcsak a Balti-tenger szépségének sajátos kifejezője, hanem Somlyó hosszabb elmélkedésének kiindulópontja is. Az alkonyi tenger, elsősorban a kikötőbe beúszó bárka látványa eszébe juttatja a szerzőnek Paul Valéry egyik szonettjét, melyet ő fordított magyarra „,a háború utolsó esztendejében" (Somlyó, 1954. 53.), valamint filozófiai és politikai reflexióra is készteti:

A szonett változtathatatlan, merev ellentétben állítja elénk a társadalmat. Egyik oldalon a „Politika” - ilyesformán, nagybetüvel és idézőjelek közt -, mint aminek az egyszerű ember kérlelhetetlenül ki van szolgáltatva: a Vezér, aki már készíti „villámló szavát”, melytől „majd tébolyult hajnal riad az estre”. A másik oldalon a „,boldog, gondtalan” halász, aki mit se sejt a ráleselkedő veszélyről, ,,a mennykőről, amit már robbant a vezér". Boldog - nem azért, mert felismeri a veszélyt és szembe tud szállni vele, hanem éppen azért, mert nem tud róla, s mert a költő szerint, ha tudna, az tehetetlenségében csak boldogtalanná tenné. (Somlyó, 1954. 53.)

Az összefoglalást követően Somlyó még hozzáteszi: „Évek óta eszembe se jutott ez a vers s most egyszerre felderengtek előttem éles képei” (Somlyó, 1954. 53.). A „most” arra a pillanatra vonatkozik, amikor a magyar író Gdynia egyik dombjának tetején állva csodálja a tenger látványát. A Visztula sellője szerzője a Valéry versében szereplő halásznak sajátos ellentétét abban a halászban látja, aki sejtése szerint a Balti-tenger vizein úszó bárkában ül:

Ebben a bárkában is biztosan egy halász ül. Hálóját bontogatva nézi a csillogó zsákmányt, családjára gondol, talán a szövetkezet ügyes-bajos dolgaira is s közben, ebben a pillanatban is, nem egy „vezér” tervel villámló terveket a világon az egyszerü halászok ellen. Csakhogy ez a kis bárka már nem az, amelynek halásza „mit se sejt a mennykőröl”. Ha boldog, a veszedelem ismeretében és a maga milliókéval összefont ereje tudatában az. (Somlyó, 1953. 53-54.)

Somlyó továbbá kitér egy másik halászbárkára is, amely „a Csendes Óceánon úszott a tonhalak nyomát követve” és amely „félelmetes zsákmánnyal megrakva kötött ki a japán kikötőben”, tudniillik „,a modern mennykő [visszautalás Paul Valéry szonettjére - M. G.], a hidrogén-bomba iszonyatos sugárzását rakodta ki a partra, emberek és halak testében egyaránt" (Somlyó, 1954. 54.). Ez egy költői, metaforikus utalás a Daigo Fukuryu Maru japán halászhajó személyzetének tragikus sorsára; a japán matrózokat az amerikai hidrogénbomba robbanásából származó radioaktív hulladék fertőzte meg. Ez az eset 1954. március 1-én történt, vagyis röviddel a magyar költő lengyelországi utazása elött. A fentebb idézett hosszabb részlet utolsó két mondatát („Csakhogy ez a kis bárka...” és „Ha boldog...”) az akkori nemzetközi helyzetet, vagyis a hidegháború valóságát figyelembe véve politikai és kissé propagandisztikus nyilatkozatnak is tekinthetjük - pontosabban: elég világos utalásnak az úgynevezett „béketáborra”, vagyis a kommunista blokk országaira (a Szovjetunióval az élen). A gdyniai kikötőbe beúszó

9 Érdemes megjegyezni, hogy a Balti-tenger vize általában csak szélcsend idején kék színű. 
bárka feltételezett halásza lengyelként része ennek a nagy, több millió „tagot” számláló (,a maga milliókéval összefont ereje tudatában az”), biztonságot garantáló nemzetközi kommunista „családnak”. „Lehetnek-e boldogok a tengerek bármely pontjának egyszerü halászai, ha nem tudják, mi történt japán társaikkal? S lehetnek-e boldogok, ha tudják, s tovább is úgy ringanak a szelíd habokon, mint akik nem tudnak róla?" - teszi fel e szintén kicsit propagandisztikus ízü, retorikus kérdést a szerző, majd a filozófiai és politikai elmélkedések befejezéseként gondolatban újra a Balti-tenger vizén úszó halászbárkához kanyarodik vissza: „Kis bárka, ott a kikötő fehér karjai közt, a kék tengeren virágzó sárga szirom, jelképe te az egyszerü életnek, - ma olyan vagy nekem, mint egy kiáltás" (Somlyó, 1954. 54.).

A Balti-tenger látványa teljesen elragadja Somlyót, szinte mágikus erővel hat rá, hipnotizálja őt; nemcsak megtölti a magyar költő tengerparti szállodája szobáját, hanem úrrá lesz érzelmi világa fölött is. A magyar író lírai tudósításában a tenger nagy müvész, aki saját módjára alakítja a valóságot:

TENGER - csak így egyszerüen, ahogy kimondom. Megkaptam kulcsomat a portán, akkorát, mint egy középkori városé, felmentem a szálloda lépcsőjén, benyitottam a szobámba és kitártam az ablakot. Ott volt a tenger a szobámban. A tenger, az óriási gyermekjáték, a perpetuum mobile, a karmester nélkül összhangban szóló zenekar, a nagy zenész és nagy festő, színek szakadatlan keverője, dallamok fáradhatatlan kitalálója.

$[\ldots]$

Kinyitom az ablakot és itt van a szobámban a tenger. Nem is hagy el aztán egy pillanatra sem, amíg csak én el nem hagyom a partját. Ülök az ablakban egész nap s reggeltől késő estig mintha egyéb se volnék, csak valami hallatlan fény- és hangérzékenységü müszer, amely a hangok váltakozását, az árnyalatok cseréit jelzi, a megnevezhetetlen színeket és feljegyezhetetlen dallamokat gyüjti.

Rémülten kelek fel székemböl este a fároszok hunyorgatása közt, mely olyan, mint valami ellenállhatatlan útrahívás. Hosszú órákat ültem mozdulatlanul valami megbűvölt varázsban, szinte léttelenül. Nincs semmi a világon, ami mellett az ember úgy el tudna törpülni, mint a tenger mellett. (Somlyó, 1954. 48-49.)

A Gdyniából a Hel-félszigetre ${ }^{10}$ hajózó Pethő Tiborra szintén nagy hatást gyakorolt a (nyílt) tenger látványa, amely gyermekkori vágyakat ébresztett újra benne, s nagy tengeri utazások és kalandok hangulatát idézte fel:

Nyílt tenger! Milyen távoli, izgató fogalom ez! Benne van gyermekkorunk kalandos olvasmányainak minden romantikája, az a félelmetes, ismeretlen világ, amelyben napokon és heteken át néhány tízméternyi padlódeszka az egyetlen szárazföld, egyébként közel s távolban csak a végtelen, rejtélyes víztömeg. (Pethő, 1956. 139.)

A Balti-tenger és partjai fontos történelmi események színterei is voltak; néhányukról olvashatunk A Visztula sellöje, A Kárpátoktól a Balti-tengerig, valamint a Varsói hajnal lapjain.

Somlyó György nemcsak gyönyörködik az alkonyi tenger látványában, vagy ihletet merítve belőle elmélkedik a Daigo Fukuryu Maru tragédiájáról és a világbéke kérdéséről, hanem hangsúlyozza azt is, hogy a Balti-tenger tanúja volt az egész világtörténelem egyik legfontosabb eseményének, az októberi orosz forradalomnak. Somlyó az

10 A Hel-félsziget a lengyel tengerpart része, nem messze fekszik a „Hármasvárostól”. 
Auróra híres orosz cirkálót idézi meg, amelynek egyik ágyújából leadott lövés adott jelet (az elterjedt közhit szerint) a szentpétervári Téli Palota ostromára, s így aztán a hajó az októberi forradalom jelképévé lett. Azt lehet tehát mondani, hogy az októberi forradalom a Balti-tenger partján „született meg” (bár maga az Auróra cirkáló a Finn-öbölbe torkolló Néva folyón horgonyzott). Éppen ezért a magyar költő számára, aki - ahogy az A Visztula sellöje narrációjából kitünik - a szocialista rendszer buzgó híve, a Balti-tenger fontosabb, mint a Földközi-tenger, amelynek partjai az európai kultúra bölcsőjének számítanak:

Közel két évezreden keresztül a Földközi-tenger partjainak voltak a legfontosabb emlékei az emberiség történetéről. De az Auróra ágyúinak világraszóló dörrenését $e z$ a tenger verte vissza itt elöttem, emlékét ezek a partok örzik. Ha az ember kiszakítja magát a hullámok mindig új és új karokkal ráfonódó veszedelmes öleléséből és az üresen ragyogó messzeség büvöletéből, szemben azokat a partokat véli látni, amelyek elöször hirdették meg minden partoknak és minden tengereknek az új emberi történelem üzenetét. (Somlyó, 1954. 49.)

A jelen tanulmány témája szempontjából különösen fontos és érdekes az, hogy a Baltitenger szemtanúja volt a második világháború kitörésének, amire költői módon mutat rá Ruffy Péter, a Varsói hajnal szerzője. A könyvében leírja azt a hajókirándulást, amelyet egy nyári vasárnapon (ahogy kiderül a szövegből, 1959 augusztusában) tett az Okrzeja nevü sétahajó fedélzetén a Westerplatte-félszigetre, a második világháború első csatájának színhelyére. A westerplattei csata a német invázió első csatája volt: a Schleswig-Holstein csatahajó sortüzet nyitott a Westerplatte-félszigeten állomásozó lengyel helyőrségre (Szokolay, 1996. 173.). ${ }^{11}$ Ruffy a „nyílt tenger felé vezető” (Ruffy, 1961. 38.) Ötfütty-öböl vizein hajózott; itt érdemes megjegyezni, hogy a szerző

Somlyó György nemcsak gyönyörködik az alkonyi tenger látványában, vagy ihletet merítve belóle elmélkedik a Daigo Fukuryu Maru tragédiájáról és a világbéke kérdéséról, hanem hangsúlyozza azt is, hogy a Balti-tenger tanúja volt az egész világtörténelem egyik legfontosabb eseményének, az októberi orosz forradalomnak. Somlyó az Auróra híres orosz cirkálót idézi meg, amelynek egyik ágyújából leadott lövés adott jelet (az elterjedt közhit szerint) a szentpétervári Téli Palota ostromára, sígy aztán a hajó az októberi forradalom jelképévé lett. Azt lehet tehát mondani, hogy az októberi forrada-

lom a Balti-tenger partján „született meg” (bár maga az Auróra cirkáló a Finn-öbölbe torkolló Néva folyón horgonyzott).

11 Tegyük hozzá, hogy a második világháború első harci eseménye valójában a Wieluń nevű nyugat-lengyelországi város bombázása volt, de a Westerplatte-félsziget vált a háború kitörésének jelképévé. 
minden valószínűség szerint a Holt Visztula nevű folyó torkolati szakaszát nevezi tévesen Ötfütty-öbölnek. ${ }^{12}$

A magyar szerző hủen adja vissza a nyári sétahajózás sirályokkal övezett idillikus hangulatát, valamint a forgalmas tengeri kikötő vidám, élénk légkörét:

Nyár van, és vasárnap, és tengerkék az ég. Sirályok röpködnek, cikázó égi táncot járva, az ég felé libegve, aztán lezuhanva, majd újból a magasba szállva, szeszélyes girlandokat rajzolva a levegőég langyos melegére. Tíz, húsz, száz sirály kíséri a hajót, megannyi égi balerina, fehér balettcipőben. [...] Olyan ez a sirálytánc, ez a nyári égi tánc, mint boldog szertartás, amely jókedvet kavar - a gyermekek sikoltanak, a papák fényképeznek, a mamák rettegve vonják vissza a korláttól gyermekeiket. A víz színe tengerzöld, az ég sejtelmesen kék, a hajó nyitott fedélzetének padjain incselkedve és kacagva szerelmesek bújnak össze. Ebbe a nyári kékbe, boldog tengerzöldbe, e meghitt világba olykor bolondos staccatókat kiáltanak bele a sirályok.

Az öböl, amelyen lágyan úszunk, a nyílt tenger felé vezet. Külföldi teherhajókkal, személyszállító gőzösökkel, fehér vitorlásokkal találkozunk. Minden feltünő hajó esemény. [...] Átkiáltunk a hajókra mindenféle nyelven. Köszöntünk lengyelül, franciául, angolul, oroszul, valaki svédül, én meg, mintha értené valaki, csökönyösen magyarul. Az öbölben randevúzik a világ [...] (Ruffy, 1961. 38.)

De ez az idill véget ér, a vidám hangulat teljesen megváltozik, amikor az Okrzeja egyik matróza ,a hajó tatjára ugrik [...] karját széttárja, mint próféta a pusztában, azután a vízre mutat” és kimondja az „itt” szót. Ez az „itt” a második világháború kitörésének helyére vonatkozik. A Varsói hajnal e részletének narrációjában a Balti-tenger a világtörténelem „részesévé” válik:

Az Ötfütty-öbölben vagyunk, a Balti-tenger és a történelem tenyerén. ${ }^{13}$ Itt, ezen a ponton ${ }^{14}$, a hangosan morajló vizen dördült el a náci Schleswig-Holstein ,iskolahajó" negyvenöt ágyúja - jeladás a második világháborúra - egyszerre, akkor... (Ruffy, 1961. 40.)

A westerplattei csatáról, magáról a Westerplatte-félszigetről még lesz szó a tanulmány további részében, amely Gdańsk Somlyó György, Pethő Tibor és Ruffy Péter által felrajzolt képét mutatja be.

Ha már a Balti-tengernek a történelemben való szerepéről van szó: Ruffy Péter a Varsói hajnalának egy másik fejezetében a Hel-félszigeten a második világháború idejében lezajlott két harci eseményről olvasunk. A Hel-félsziget, amely Ruffy szerint „éles pengéjével a tengerbe hasító" kardra emlékeztet (Ruffy, 1961. 177.), hősies lengyel ellenállás színhelye volt 1939 őszén (a lengyelek a német csapatok ellen védekeztek); a Hel-félsziget védését az úgynevezett szeptemberi hadjárat egyik legfontosabb, 1939. szeptember 1-étől október 2-áig tartó harci eseményének tekintik; a lengyeleknek 1939. október 2-i kapitulációja pedig e hadjárat egyik végső aktusa volt. A Hel-félsziget második világháborús történetének másik fontos eseménye a Wehrmacht katonáinak a Vörös

12 A Holt Visztula e szakaszánál a gdański tengeri kikötő van. A Holt Visztula e szakaszának kanyarodását, amelytöl ez a folyó a Balti-tengerbe (pontosabban: a Gdański-öbölbe) közvetlenül torkolló, úgynevezett Kikötői Csatornaként folytatódik, az Ötfütty-kanyarodásnak (Zakręt Pięciu Gwizdków) hívják - ott horgonyzott a fentiekben említett Schleswig-Holstein német hajó, amikor szeptember 1-én sortüzet nyitott a lengyel katonákra. Ez lehet a magyarázata Ruffy tévedésének. Eltekintve a felsorolt földrajzi részletektől, Ruffy útleírásának narrációjában az Ötfütty-öböl bizonyos mértékben a Balti-tenger részének tekinthető.

13 Kiemelés: M. G.

14 Vagyis pontosabban az Ötfütty-kanyarodásban. 
Hadsereggel szembeni védekezése volt a háború legvégén, 1945. májusában.

Ami az 1945-ös évi eseményt illeti: a magyar újságíró tévesen állítja, hogy a németek május végéig ellenálltak; az viszont igaz, hogy sokáig védekezetek a szovjetek ellen (csak május 9-én adták fel magukat; a Hel-félsziget a német fegyveres ellenállás egyik utolsó pontja volt) (Kardas, 2011. 165-186.). Az az állítás pedig, hogy - Ruffy szavait pontosan idézve - „Hel felszigetén, a kasubok $^{15}$ földjén ért véget a második világháború" (Ruffy, 1961. 177.), csak részben felel meg a valóságnak. Lehet, ezzel Ruffy a sors, illetve a történelem igazságosságára utalt, hiszen a Hel-félszigeten a háború elején a lengyelek adták meg magukat, a háború legvégén pedig, ahogy már volt szó róla, a németek kapituláltak (a Vörös Hadsereg által elfoglalt félsziget pedig végül megint lengyel fennhatóság alá került). Ezt a lengyel perspektívát figyelembe véve egyet lehetne érteni Ruffynak a fentiekben közölt állításával - szimbolikus értelemben a Hel-félsziget tényleg a második világháború befejezése színhelyének tekinthető.

A Balti-tenger összképének talán leginkább szembetünő vonása a szocialista Lengyelország életében betöltött fontos szerepe. Föként Pethö és Ruffy könyvében jut ez érvényre nyomatékosan. Ennek jobb megértését elősegítendő szükséges utalni arra, hogy a második világháború befejezése után, a jaltai és a potsdami konferencia döntései alapján újonnan húzták meg Lengyelország határait. Nyugaton olyan területekkel gyarapodott, amelyek a háború előtt Németországhoz tartoztak - többek között hosszabb tengerpartot is kapott az ország, a háború előtti állapothoz képest. ${ }^{16} \mathrm{~A}$ tenger így még nagyobb jelentőségre tett szert, mint a két világháború közötti időszakban. Meg kell azonban jegyezni, hogy a második világháború előtti Lengyelország kormánya számára fontos volt a tengeri gazdaság létrehozása, valamint egy lengyel tengeri kikötő

\section{A Balti-tenger összképének} talán leginkább szembetúnó vonása a szocialista Lengyelország életében betöltött fontos szerepe. Fóként Pethó és Ruffy könyvében jut ez érvényre nyomatékosan. Ennek jobb megértését elósegítendô szükséges utalni arra, hogy a második világháború befejezése után, a jaltai és a potsdami konferencia döntései alapján újonnan

húzták meg Lengyelország határait. Nyugaton olyan területekkel gyarapodott, amelyek a háború elótt Németországhoz tartoztak - többek között hoszszabb tengerpartot is kapott az ország, a háború elótti állapothoz képest. A tenger így még nagyobb jelentôségre tett szert, mint a két világháború közötti idószakban. Meg kell azonban jegyezni, hogy a második világháború elötti Lengyelország kormánya számára fontos volt a tengeri gazdaság létrehozása, valamint egy lengyel tengeri kikötó megépitése (elsôsor-

ban azért, mert Danzig Szabad Város német hatóságai korlátozták az ottani kikötónek a lengyelek általi használatát).

15 Kasubok: a pomeránoktól származó szláv népcsoport, az észak-lengyelországi Pomerániai vajdaság területén élnek.

16 Az úgynevezett Második Lengyel Köztársaság idején (1918-1939) a lengyel tengerpart hosszúsága 147 kilométer volt, a második világháború után már sokkal több, 497 kilométer (Szokolay, 1996. 199-200.). 
megépítése (elsősorban azért, mert Danzig Szabad Város német hatóságai korlátozták az ottani kikötőnek a lengyelek általi használatát). A lengyel kormány döntése alapján Gdyniában megépült tehát a nagy és modern tengeri kikötő (Gdynia ezáltal halászfaluból nagyvárossá lett). Ez lett az országnak a tenger felé, és ezáltal a nagyvilágra nyíló talán legfontosabb (a lengyel köztudatban elterjedt állítás szerint egyetlen) ablaka (Bilska, 2018. 7.).

Ruffy Péter már a Varsói hajnalnak a Lengyel tájak címủ első fejezetében rámutat arra, hogy Lengyelország mennyit nyert a potsdami döntésnek köszönhetően, ami a tengerhez való sokkal nagyobb hozzáférést illeti:

A régi, „versailles-i” Lengyelországnak egyetlen kis ablaka nyílt a tengerre. Egy kis „,fortocska”, nem több. Az új, a „potsdami” Lengyelországnak egész arca a tengerre néz. Lengyelország tengeri ország, tengeri hatalom, hajói Ghanától Indiáig közlekednek, Lengyelország nem ,fejeződik be” Gdańsknál vagy a Hel-félszigetnél, hanem folytatódik a tengereken, ahol lengyel hajók, lengyel halászok, lengyel matrózok járnak. Lengyelország kitágult - nagyvilággá nőtt. (Ruffy, 1961. 14.)

A fentebb idézett, az egész Varsói hajnal stílusára jellemző pátosszal és lelkesedéssel teli részlet egyrészt a lengyel tengerhajózásnak - közvetett módon az egész lengyel tengergazdaságnak, illetve tengerpolitikának ${ }^{17}$ - valódi nagymértékü fejlödését és jelentőségét fejezi $\mathrm{ki}^{18}$; másrészt pedig bizonyos mértékben propagandisztikus jellegünek is tekinthető, beleíródik ugyanis abba a szocialista újjáépítéssel kapcsolatos, a szovjet blokk talán minden országában észrevehető tendenciába, amely a szocializmus sikereit, az „általa” elért eredményeket hangsúlyozza. Ennek az egyik megnyilvánulása maga a patetikus stílus. Ruffy viszont elhallgatja azt, hogy a potsdami (és jaltai) konferencián Lengyelország nemcsak szerzett új területeket (a németektől, többek között nagyobb hozzáférést a tengerhez), hanem el is vesztette a keleti területeit a Szovjetunió javára. ${ }^{19}$ És egyetlen szóval nem utal arra sem, milyen fontos szerepe volt Gdynia kikötőjének a Második Lengyel Köztársaság idején, csak a háború utáni lengyel „tengerhódítás” sikereiről ír. Bár a háború előtti Lengyelországnak - Ruffy szavait idézve - csak „egyetlen kis ablaka nyílt a tengerre”, mégis ez a „kis ablak”, amely alatt elsősorban Gdyniát, az újonnan épült kikötőjét (szélesebb értelemben az egész 147 kilométer hosszú lengyel tengerpartot is) kell érteni, fontos volt az egész ország számára. A kikötőnek és magának a városnak, Gdyniának a megépítése ${ }^{20}$ nagy sikere és érdeme volt az akkori lengyel állami hatóságoknak. S mivel a szocializmus kora elítélte őket, azt feltételezhetjük, hogy Ruffy Péter - többé vagy kevésbé szándékosan (lehet, hogy a lengyel „,vendéglátói” hatására) - mintegy „lenézi” Gdyniának a két világháború közötti Lengyelország tengerpolitikájában játszott jelentőségét (ld. „A régi, »versailles-i« Lengyelországnak egyetlen kis ablaka nyílt a tengerre. Egy kis »fortocska«, nem több.”). Hozzá kell tenni, hogy a szerző megismétli e véleményét és észrevételeit az útleírásának a Népvándorlás a $X X$.

17 Vö. az alábbiakban közölt hosszabb idézett részlet is („A lengyel tájba új elem vegyült...”). .

18 Ami például az idézetben említett Ghanát illeti: 1958. decemberében a Tczew nevü lengyel gőzös elindult az észak-nyugat lengyelországi Szczecinből Ghanába és Guineába; ezzel kezdetét vette a tengeri összeköttetés Lengyelország és Nyugat-Afrika között (Wroński és Zwolakowa, 1966. 87.).

19 Természetesen az is valószínü, hogy ez nem volt szándékos a részéről - teljesen érthető okok miatt sem lett volna szabad írni erről.

${ }^{20}$ Gdynia városi rangot 1926-ban kapot, előbb halászfalu volt. Gdynia városiasodása a tengeri kikötő építésével volt kapcsolatos. 
században címü fejezetében, amelyben az úgynevezett „Visszaszerzett Területek”21 kérdésével foglalkozik:

A két világháború között Lengyelországnak csak egyetlen kicsiny ablaka nézett a tengerre: Gdynia kikötőváros. A potsdami döntés alapján Lengyelország tengeri hatalommá vált $[\ldots]$ (Ruffy, 1961. 124.)

Visszatérve az előző részlethez: a Varsói hajnal szerzője a továbbiakban folytatja a gondolatait a Balti-tenger szerepéről a háború utáni Lengyelországban, rámutatva arra, hogy a tenger új jelenség nemcsak az ország földrajzában, hanem a gazdasági, társadalmi életében is, és sajátos kihívást jelent a lengyelek számára. A tenger ,jelenléte” színesíti Lengyelország tájképét:

A lengyel tájba új elem vegyült: a tenger. A lengyel földrajz tizenöt éve új tájjal ismerkedik, a lengyel ember most tanulja a tengert. Megtanul hálót kötni, halászni, világot járni, megszokja a hideg szeleket, megismeri a nagy tengeri országutakat. Lengyelország térképén megjelentek az élénk, zsúfolt, hatalmas nemzetközi forgalmat lebonyolító kikötők, a kedves halászfalvak, ahol az élet korántsem olyan idillikus. (Ruffy, 1961. 14-15.)

Ruffy Péter a Varsói hajnal e részletében is, ugyanúgy, mint az előzőleg idézett szakaszban, egy kicsit eltorzítja a tényeket. Lengyelország - amint arról már volt szó - a II. világháború után, a Balti-tengerhez való nagyobb hozzáférésnek köszönhetően, nagy mértékben kifejlesztette tengergazdaságát és tengerpolitikáját, de emlékezni kell arra is, hogy a tenger a háború előtti időszakban is jelen volt, sőt fontos szerepet töltött be az ország életében (Gdynia megépítése és az ottani kikötő sikeres müködése). A magyar újságíró pont az „új”, szocialista Lengyelországnak a tengerrel kapcsolatos feladataira és sikereire akarja ráirányítani a magyar

Ruffy Péter a Varsói hajnal $e$ részletében is, ugyanúgy, mint az elózóleg idézett szakaszban, egy kicsit eltorzitja a tényeket. Lengyelország - amint arról már volt szó a II. világháború után, a Baltitengerhez való nagyobb hozzáférésnek köszönhetóen, nagy mértékben kifejlesztette tengergazdaságát és tengerpolitikáját, de emlékezni kell arra is, hogy a tenger a háború elótti idószakban is jelen volt, sót fontos szerepet töltött be az ország életében (Gdynia megépitése és az ottani kikötó sike-

res müködése). A magyar újságíró pont az „új”, szocialista Lengyelországnak a tengerrel kapcsolatos feladataira és sikereire akarja ráirányitani a magyar olvasóközönség figyelemét (a fentebb idézett, lelkesedéssel és némi pátosszal teli részletnek célja elsósorban

ilyen irányú hatást kelteni az olvasóban).

21 „Visszaszerzett Területek” a hivatalos neve a háború utáni Lengyelország nyugati és északi területeinek, amelyeket a jaltai és potsdami békekonferencia alapján elvették a németektől és a lengyel államhoz csatolták. Ez a háború utáni, németellenes politikai és történelmi narráció, illetve németellenes propaganda jegyeit viseli magán, arra utal, hogy e területek valaha „ősi” lengyel földek voltak, és most, a második világháború befejezése után visszakerültek a „gazdájukhoz”, vagyis Lengyelországhoz. 
olvasóközönség figyelemét (a fentebb idézett, lelkesedéssel és némi pátosszal teli részletnek célja elsősorban ilyen irányú hatást kelteni az olvasóban).

A magyar újságíró a lengyel tengeri kikötőket is említi, színes, idillikus, de ezáltal egy kicsit sztereotip, „képeslapszerü”, a „tengeri romantikával” egyező, de a valóságnak csak részben megfelelő képet vázolva fel a kikötői életről:

A lengyel tájhoz hozzátartozik a Báthory tengerjáró Gdynia kikötőjében, és hozzátartoznak a svéd, szovjet, francia, német, finn, norvég, spanyol matrózok, azok a dalok, amelyeket énekelnek, a kocsmák, ahol vigadnak, és hozzátartoznak a világ minden részéből érkező hajók, amelyeket megpillant az ember a kikötőkben. (Ruffy, 1961. 15.)

Ruffy az északnyugat-lengyelországi Szczecin kikötővárosban ${ }^{22}$ lett látogatásáról beszámolva is a Balti-tenger jelentőségére mutat rá, idézve a kikötőparancsnok szavait:

S hajóink [...] tizenöt kemény, súlyos esztendő után ma az egész világon járnak. A Gdyniában állomásozó „Báthory” személyszállító hajó bonyolítja le az utasforgalmat Lengyelország és Amerika között. Havonként indul Gdyniából a kanadai Montrealba. A lengyel „Tobruk”, „Narvik” vagy „Białystok” nevü hajók Lengyelország és India közt járnak. Alig van tengeri kikötő a nagyvilágban, ahol ne fordulnának meg lengyel személy- vagy teherszállító hajók. (Ruffy, 1961. 137.)

„A lengyel hajósnép lett” (Ruffy, 1961. 137.) - teszi hozzá a Varsói hajnal szerzője.

A három szerző a Balti tenger jelentőségét egyaránt a lengyel kikötők sikeres müködésének perspektívájából mutatja be. „Lengyelország tengeri ország, tengeri hatalom” (Ruffy, 1961. 137.) - Ruffy Péter idézett szavai Pethö Tibor A Kárpátoktól a Baltitengerig címü útirajza mottójának, vezérgondolatának is tekinthetők. Pethő egy fiatal lengyel tengerésztisztnek köszönhetően ismeri meg a tenger szerepét a „népi” Lengyelország életében, akivel a Hel városából Gdyniába tartó hajó fedélzetén ismerkedett meg. ${ }^{23}$ A szerző egybefüggő hosszabb kijelentésként közli a lengyel tiszt válaszait azokra a kérdésekre, amelyeket a magyar újságíró, illetve csehszlovák és román kollégája tett fel neki (magukat a kérdéseket nem közli a szerző).

A Pethő beszélőpartnere közölte információk a tengernek az ország gazdasági életében való jelentőségére vonatkoztak. A tengerésztiszt a lengyel tengerhajózásnak, a lengyel kereskedelmi flottának a második világháború utáni fejlődéséről, a lengyel hajógyárak sikeres és eredményes müködéséről tájékoztatta útitársait. Ahogy már többször szó esett róla, a második világháború utáni Lengyelország erősen felfejlesztette gazdaságának a tengerrel kapcsolatos ágait; nem merülve bele a részletekbe azt lehet feltételezni, hogy a lengyel matróz által megadott adatok és információk lényegüket tekintve megfelelnek a valóságnak. A tengerésztiszt Pethő Tibor által közölt válaszaiba mégis propagandisztikus elemek is vegyülnek. Nagyon szembetünő például a Második Lengyel Köztársaság tengergazdaságának, tengerpolitikájának elítélése:

A háború előtt a lengyel hajók brutto regiszter tonna értéke 100000 körül mozgott, s a hajók jobbára idegen tőke ellenőrzése alatt álló vállalatok tulajdonában

22 Szczecin majdnem 70 kilométeres távolságban fekszik a Balti-tengertől, az Odera és a csatornái, illetve mellékágai mentén.

${ }^{23}$ A megismerkedés körülményeiről ennyit olvasunk: „Heliben [vagyis Hel városában - M. G.] három fiatal tengerésztiszt is felszállt a hajóra. Egyikük, mikor megtudta, hogy külföldi újságírók vagyunk, beszédbe elegyedett velünk és készségesen válaszolt kérdéseinkre [...]” (Pethő, 1956. 140.) 


\section{voltak. A hajók a nemzetközi tőkeérdekeltségek által diktált feltételek mellett}

dolgoztak. $^{24}$ (Pethö, 1956. 140-141.)

A fiatal lengyel tiszt kijelentése a sikerpropaganda jegyeit viseli magán, aminek jó bizonyítéka már a Pethő által közölt első részlet is (amely egyébként szintén tartalmaz a háború előtti Lengyelország hatóságaira irányuló kritikát):

Lengyelország tengeri állam [...] Ez a meghatározás, amely a két világháború között eltelt húsz esztendő alatt üres szólam volt csupán, a népi Lengyelország fennállásának tíz éve alatt telt meg eleven tartalommal. Országunknak most mintegy ötszáz kilométer hosszúságú tengerpartja van. Az Odera és a Visztula között jelentős kikötők, Gdańsk, Gdynia, Szczecin tették lehetővé, hogy Lengyelország ipari, mezőgazdasági és tengeri állammá alakult át. (Pethő, 1956. 140.)

Somlyó György a lengyelországi útleírásában szintén említi a Balti-tenger Lengyelország és a lengyelek életében betöltött szerepét, de csak enyhe és közvetett utalás formájában, s nem annyira patetikusan, mint például a fentebb idézett Ruffy Péter („A régi, »versailles-i« Lengyelországnak egyetlen kis ablaka”, „A lengyel tájba új elem vegyült...”), és nem is olyan hosszú, adatokkal telezsúfolt szöveg formájában, mint Pethö Tibor beszélgetőtársa. Somlyó az általánosan vett tengernek és a partjain élö embernek az összefüggésére mutat rá:

A tengeri táj különbözik minden földi tájtól. A síkság, a hegyvidék, a falu, a város - az ember lakóhelye, tevékenységének természetes színtere. A tenger nem lakóhely, nem talaja, csak szegélye az életnek. És mégis, a tengerparti ember életének minden pillanatát a tenger határozza meg. Az anyai, a nagy, a veszedelmes és a szépséges öselem. (Somlyó, 1954. 48.)

A Balti-tengernek a szocialista Lengyelország számára jelentős szerepét közvetett módon, a Gdynia kikötőjének perspektívájából mutatja be a szerző. Somlyó az említett lengyel tengeri kikötőt „Észak-Európa egyik legszebb, leggazdagabb forgalmú kikötőjének” nevezi, és rámutat a magyar külkereskedelemben betöltött szerepére is: „Gdynia egy kicsit a mi kikötőnk is" - olvassuk.

\section{Gdańsk képe a három útleírásban}

Gdańsk a lengyel tengerpart legfontosabb városa, s mint ilyen, mind a három szóban forgó magyar író, de különösen Ruffy Péter és Pethő Tibor lengyelországi utazástörténetében fontos helyet foglal el. Egyaránt szó esik bennük a város lengyel történelemben és a világtörténelemben játszott szerepéröl, dicső múltjáról, a második világháború pusztító hatásáról és az újjáépítéséről. Mindezekkel összefüggésben Gdańsk öt, egymással szorosan összefüggő szempontból kerül megvilágításba az útleírások hasábjain: mint a második világháború kitörésének színhelye, mint lerombolt és újjászületett (szocialista) város, mint a lengyelek városa, mint a történelmi múlt emlékhelye és mint kikötőváros. Tekintettel a téma összetettségére, jelen tanulmány csak az első két szempontra fókuszál.

Mind a három szerző rámutat Gdańsk helyére a világtörténelemben, tudniillik arra, hogy ebben a városban tört ki a második világháború (emlékeztetőül: a Gdańsk határában

24 Kiemelés: M. G. 
levő Westerplatte-félszigeten állomásozó lengyel katonák elleni támadás a német hadjárat első csatája volt).

Ruffy Péter személyesen járt a második világháború első csataterén, a gdański tengeri kikötő vizein és magán a félszigeten is, azon a területen, ,,amely elöször szerepelt a második világháború hadijelentéseiben" (Ruffy, 1961. 41.). Ahogyan már szó volt róla, Ruffy az Okrzeja nevü sétahajó fedélzetén hajózott az Ötfütty-öböl vizén, lengyelek társaságában, s egy matróz kiáltása (,itt”) hívta fel a figyelmét a történelmi jelentőségü helyre, ahol eldördült a 2. világháború nyitányát jelentő sortűz. De ennek az „itt” szócskának e fejezetben több értelme is van:

Az Ötfütty-öbölben vagyunk, a Balti-tenger és a történelem tenyerén. Itt, ezen a ponton, a hangosan morajló vizen dördült el a náci Schleswig-Holstein ,iskolahajó" negyvenöt ágyúja - jeladás a második világháborúra - egyszerre, akkor...

Itt kezdődött a második világháború. Itt kezdődött holta a millióknak, régi lakásomnak, barátaimnak, több mint százezer doni halottnak és a sok milliónak a világ szétszórt csataterein. Itt kezdődött Varsó, Sztálingrád, Berlin pusztulása, az ausradierung, a stukahalál; itt kezdődtek a sírok, temetők, fakeresztek. Mintha fekete fátyol lenne ez a víz, ez a part, ez a levegő, ez a föld; fekete fátyol, mely ráterült az anyákra Moszkvában és Münchenben, Pesten és New Yorkban. Itt kezdődött a gyász.

Ez a huszadik évforduló. Az én gyászom is lengyel szemekben reszket, lengyel pillákon ül; már-már ruháit szeretné tépni az ember, mint a dervisek. De csak néz, tikkadtan, fojtva:

Itt?

Elsüllyedt emberek, szétvert családok, elmállott embercsontok, temetők lakói, kik valaha éltek - kiket valaha szerettem, csókoltam; kikkel együtt ittam, nevettem, dolgoztam, éltem, hol keresselek? (Ruffy, 1961. 40.)

A magyar újságíró szemében a Westerplatte-félsziget és az „Ötfütty-öböl” vize nemcsak a lengyel, hanem a világtörténelemnek is a része, valamint az ő személyes tragédiája is - Ruffy kétszer is utal arra, hogy a háború áldozatai között voltak a barátai, illetve hozzátartozói is (,kiket valaha szerettem, csókoltam; kikkel együtt ittam, nevettem” és így tovább).

Ruffy a Varsói hajnal Gdańsknak szentelt fejezetében a rá jellemző költői pátosszal írja le a westerplattei csata menetét. Ez a leírás, valamint a csata körülményeinek bemutatása tényeken alapul, de a szerző a díszes, emelkedett stílusnak köszönhetően bizonyos mértékben „ki is színezi” az eseményeket, elsősorban a leírás drámaiságára fektetve a hangsúlyt. Úgy tünik, hogy Ruffy elsősorban fel akarja rázni az olvasót, fel akarja kelteni benne a halálos veszély érzését, s végül, de nem utolsósorban, hangsúlyozni szeretné a németek kegyetlenségét és a félszigetet védő lengyel katonák rendületlen, „eposzba illö" 25 hősiességét. Ezt példázza a következő, szeptember 6-i eseményekre vonatkozó részlet, amikor is a németek valóban kétszer is fel akarták gyújtani a félszigetet borító erdőt (Tuliszka, 2011. 214-218.):

Akkor Hitler katonái a síneken benzinciszternákat toltak a félsziget felső csücskére, hogy leöntsék ezt a gyönyörü, legyőzhetetlen félszigetet, és lángra gyújtsanak mindenkit, aki még ellenáll. A hős lengyel katonák a benzintartályokba eresztették az

25 Tulajdonképpen az „eposzba illő hőssieségről” az 1944-es varsói felkelők kontextusában olvasunk a Varsói hajnalban, de e szavak jól tükrözik a westerplattei lengyel katonáknak Ruffy által megalkott képét is. 
utolsó gépfegyversorozatot, hogy a lángra lobbanó benzin tűzfüggönye még védje őket néhány percig. Miután elhalt a tüz, ott ültek az őszi balti ég alatt, várva a halált. (Ruffy, 1961. 43-43.)

Mint minden eposznak, ennek a sajátos „,westerplattei” miniatür eposznak is van föhőse - Henryk Sucharski őrnagy, a westerplattei lengyel helyőrség parancsnoka. Ruffy elbeszélésében Sucharski és katonái egyaránt az ideáljaikhoz rendületlenül hü hősökként és tragikus történelmi alakokként jelennek meg, akik már a csata kezdete elött is halálra vannak ítélve:

Azért voltak itt a katonák mind nőtlen férfiak, mert Sucharski örnagy [...] amikor érezte a világpusztulás előszelét, hazaküldött vagy áthelyeztetett mindenkit, akinek családja volt. Tudta, hogy a Westerplatte biztos halál, ha megindul a náci hadigépezet. ${ }^{26}$ Itt csak az maradjon, akit nem fog gyászolni senki, csak mindenki - akinek nincs senkije, csak a megtámadott, vérbe borult Lengyelország. (Ruffy, 1961. 41.)

A blitzkrieg már Lengyelország szívében tombolt. A Westerplatte agglegényei azonban még védekeztek. Mit vártak? Egy sort a történelemkönyvben, annyit, hogy Westerplatte hű maradt? Egy könnycseppet, amely most gördül ki elöttem egy kislány szeméből, gurulva, mint a gyöngyszem, a sírkövekre, ahol az agglegények pihennek? [...] (Ruffy, 1961. 42.)

A lengyel katonák hősiessége és elszánt harca Szondi Györgynek, a 16. századi drégelyi várkapitánynak az alakját juttatja Ruffy Péter eszébe: „A lengyelek védekeztek, mint megannyi Szondy ${ }^{27}$, még féltérden, vérbe borulva is" (Ruffy, 1961. 42.). A magyar szerző drámai erővel festi le nemcsak a csata menetét, hanem a lengyel védők kapitulációjának a pillanatát is, Sucharski őrnagy alakját állítva előtérbe:

S mikor már minden elveszett, mikor Lengyelország már nem élt, s talán csak az ég volt még lengyel a megtiport föld felett, Sucharski tengerész törével megindult a párás partokon, hogy megadja magát. Kezében vérfoltos fehér zsebkendőt lengetett. (Ruffy, 1961. 43.)

Ruffy Péter 1959 nyarán, a második világháború kitörésének huszadik évfordulóján járt a helyszínen. A háború emlékezete ekkor még eleven volt Lengyelországban, s a németellenes kommunista propaganda fontos elemének is számított. A háború lengyel emlékezetének ezt az elevenségét Ruffy a leégett és gyászoló fák költői képével adja vissza:

A félszigeten a fák gyászban állnak húsz év után is. Üstökük koromfekete, törzsük olyan, mintha villám hasított volna rajtuk keresztül. A tölgyek - úgy látszik - nem ismerik a gyászéveket. Nem ismernek feloldozást, és nem tudnak felejteni. És nem hiszik, hogy begyógyulnak a sebek, és nem is remélik, hogy van feltámadás, ahogy Sucharski szegény agglegényei sem támadtak fel haló porukból soha. (Ruffy, 1961. 42.)

A Westerplatte szelleme hatással volt Ruffyra, valamint a félszigetet vele együtt meglátogató lengyelekre és külföldiekre is: „A sírok előtt [vagyis a westerplattei helyőrség

26 Kiemelés: M. G.

27 Kiemelés: M. G. 
Marcin Grad: Három magyar a Balti-tengerné

elesett katonáinak sírjai előtt - M. G.] állunk némán, lengyelek, oroszok, magyarok, franciák" (Ruffy, 1961. 42.).

A fentebb idézett hosszabb részlet elején azt olvassuk, hogy Sucharski örnagy „hazaküldött vagy áthelyeztetett mindenkit, akinek családja volt". Ez a megállapítás tudomásom szerint eltér a valóságtól. Melchior Wańkowicz, az egyik legismertebb lengyel újságíró és riporter a Westerplatte-félsziget védelméről szóló híres riportjában ${ }^{28}$ csak annyit ír, hogy 1939. augusztus nyarán csupán a lengyel westerplattei helyörség civil alkalmazottjainak családjait küldték ki a félszigetről (egyébként maguk a civil alkalmazottak saját kívánságukra maradtak a katonákkal) (Wańkowicz, 1990. 52.). Az sem igaz, hogy a félszigeten csak nőtlen katonák (akiket Ruffy sajátos módon ,agglegényeknek" nevez) teljesítettek szolgálatot - például Leon Pająk főhadnagynak volt felesége (Drzycimski, 2009. 96.).

Úgy látszik, hogy Ruffy a Westerplatte védelmének történetét olyan elemekkel színesíti, amelyek valódisága kétséges. Ilyen továbbá Sucharski örnagy csata utáni sorsának a leírása is. A magyar szerző szerint a lengyel parancsnok a német fogságból megszökve ,szerzett egy rongyos bárkát, s azon heteken át hányódva leevezett Afrikáig" (Ruffy, 1961. 43.). Ez a megállapítás szépen belekomponálódik a westerplattei csata leírásába, de teljesen fiktív. Hasonlóan a lengyel örség kapitulációjának fentebb idézett, patetikus, költői leírásához, mely szintén eltér a tényektől (Drzycimski, 2009. 139146.). Nyitott kérdés, hogy e „,költött” vagy „kiszínezett” részek mennyire tekinthetők „lengyel hatás" eredményének, mindenestre nagy valószínüséggel feltételezhetjük, hogy a westerplattei csatáról főleg a lengyelek tájékoztatták Ruffyt.

Ahogyan már említettük, Ruffy Péter a westerplattei harcok leírásában a drámaiságra, valamint a lengyel hősies katonák dicséretére fekteti a hangsúlyt, nem pedig a konkrétumok felsorolására. A csatának általa adott bemutatása teljesen beleíródik a lengyel történetírói hagyományba. A westerplattei csata a lengyel katonaság hősiességének és harciasságának jelképe lett, sőt, lengyel nemzeti

28 1959-ben külön könyvként adták ki. Érdemes hozzátenni, hogy Melchior Wańkowicz e riportja hozzájárult ahhoz, hogy a Westerplatte-félsziget védelme lengyel nemzeti mítosszá vált (róla még lesz szó a továbbiakban), de a hitelessége vitatott a történészek körében.
Ahogyan már említettük, Ruffy

Péter a westerplattei harcok leirásában a drámaiságra, valamint a lengyel hósies katonák dicséretére fekteti a hangsúlyt, nem pedig a konkrétumok felsorolására. A csatának általa adott bemutatása teljesen bele-

iródik a lengyel történetírói hagyományba. A westerplattei csata a lengyel katonaság hốsiességének és harciasságának jelképe lett, sót, lengyel nemzeti mitosszá vált. 1939 szeptemberében kelt életre, s a második világháború után fontos szerepet töltött be a hivatalos kommunista történetírásban, de a kommunistaellenes körökben is népszerúségre tett szert - azt lehet mondani, hogy egyesitette a lengyeleket. A westerplattei csata mitosza manapság is jelen van a lengyel köztudatban, de szakmai viták tárgyát képezi. Vannak olyan történészek is, akik igyekeznek részben lebontani a csata mitoszát, $s$ az események más körülményeire és árnyalataira világitanak rá (Wasilewski, 2013). 
mítosszá vált. 1939 szeptemberében kelt életre, s a második világháború után fontos szerepet töltött be a hivatalos kommunista történetírásban, de a kommunistaellenes körökben is népszerüségre tett szert - azt lehet mondani, hogy egyesítette a lengyeleket. A westerplattei csata mítosza manapság is jelen van a lengyel köztudatban, de szakmai viták tárgyát képezi. Vannak olyan történészek is, akik igyekeznek részben lebontani a csata mítoszát, s az események más körülményeire és árnyalataira világítanak rá (Wasilewski, 2013). De ez a bonyolult kérdéskör nem tárgya a jelen tanulmánynak.

Annyit mindenestre meg kell jegyezni, hogy bármennyi tévhit és legenda is képződött a csata köré, amelynek elbeszélése általában a patetikus túlzás jegyeit mutatja, ez semmit sem von le a westerplattei lengyel katonák rendületlen, hősies magatartásából és az esemény történelmi jelentőségéből (Tuliszka, 2011. 231-239.).

Pethő Tiborban gdański látogatása során szintén tudatosul, már az első pillanatban, milyen nagy jelentőségü helyen is jár, s ezt patetikusan juttatja kifejezésre (igaz, nem annyira, mint Ruffy Péter): „Megilletődve szálltunk ki Európának azon a földrajzi pontján, ahol a második világháború első puskalövése eldördült". A háborút metaforikusan „viharnak” nevezi, amely „ebből az Aeolus barlangból [vagyis Gdańskból - M. G.] tört a világra" (Pethő, 1956. 124.). A magyar újságíró részletesen ismerteti az olvasóval Gdańsk múltját és müemlékeit, s rámutat az „új Gdańsk” építésére is. Mégis úgy tünik, hogy Pethő tudatában e tengerparti város elsősorban a második világháború kitörésének színhelyeként létezik. Bár - Ruffyval ellentétben - nem ír sokat a westerplattei csatáról, útirajza Gdańskról szóló fejezetének a címe mégis az, hogy Ahol a háború elkezdödött.

Érdekességként érdemes még hozzátenni, hogy Pethő is, Ruffy is idézi az egyik legismertebb 20. századi lengyel költőnek, Konstanty Ildefons Gałczyńskinak a westerplattei lengyel katonák hősiességét dicsérő versét. ${ }^{29}$ Gałczyński verse egyébként nagymértékben hozzájárult a „westerplattei” lengyel nemzeti mítosz létrehozásához.

A harmadik szerző, Somlyó György szintén rámutat - egyébként érdekes, szokatlan módon - Gdańskra mint a második világháború kitörésének színhelyére (erről még lesz szó a továbbiakban).

A szerzők (kisebb vagy nagyobb mértékben) írnak Gdańsk elpusztításáról is, amely a második világháború legvégén történt, 1945 tavaszán ${ }^{30}$, a német-szovjet harcok során ${ }^{31}$ és utánuk is; akkor a belvárosnak 90 százaléka pusztult el (az épületek döntő többsége a tüzvész áldozatául esett).

A Gdańsk elpusztításáért való felelősség kérdése régóta vita tárgya. A második világháború után, a Lengyel Népköztársaság idejében a hivatalos történelmi narráció szerint a város egyszerüen a harcok következtében pusztult el, vagy ezzel a németeket hibáztatták. A másik álláspont szerint (amely föleg az 1989-es rendszerváltás után terjedt el szélesebb körben) a várost (elsősorban a történelmi jellegü belvárost) a harcokban győztes szovjetek pusztították el (gyújtották fel). Mind a két nézet téves; a „kik pusztították el Gdańskot?" kérdésre adható válasz pedig nem egyértelmü (Wąs, 2012. 885-887.).

Meg kell jegyezni, a város - szinte teljes - megsemmisülésének alapvető oka a fentebb említett elszánt német-szovjet véres harcok voltak. A harcok egyik színtere többek között a belváros volt, ahol Gdańsk legszebb, történelmi épületeinek döntő többsége összpontosult. Azt is lehet mondani, hogy a város a német csapatok elszánt fegyveres ellenállásnak és a Vörös Hadsereg heves offenzívájának martalékául esett (Adolf Hitler március 24-25-én erődnek nyilvánította a várost és megparancsolta, hogy az utolsó katonáig harcolva védjék a németek). Ezenkívül a szovjetek a város elfoglalása után maguk is

29 A lengyel címe: Pieśń o żolnierzach z Westerplatte.

30 A Vörös Hadsereg fö támadása 1945. március 14-én indult el. Gdańsk felszabadulása/elfoglalása dátumának általánosan március 30-át tartják.

31 A város bombázásában amerikai repülőgépek is részt vettek. 
hozzájárultak a város megsemmisítéséhez: Gdańskot (vagy inkább a város akkori nevét használva: Danzigot) a Vörös Hadsereg katonái tiszta német, tehát ellenséges városnak tekintették, és ez is erősen ösztönözte őket a harcok után megmaradt épületek felgyújtására, elpusztítására, továbbá rablásokra, gyilkosságokra és a danzigi nők megerőszakolására (stb.) (Wąs, 2012. 885-887.). A szóban forgó magyar útleírások - teljesen érthető okok miatt - hallgatnak a szovjet katonák ezen eröszakos tetteiről. Ruffy Péter Gdańsk elpusztításáért egyedül a németeket okolja. Közli egy „Ticzner” nevü lengyel újságíróval $^{32}$ lefolytatott beszélgetését, amelynek az egyik részlete az 1945-ös katasztrófára vonatkozik:

Mikor gyulladt ki Gdańsk? [kérdezte a magyar újságíró - M. G.]

- A felszabadulást megelőző napokban.

- A vernichtungskommando gyújtotta fel?

- Ezt nem tudjuk pontosan. Feltehetően a várost elhagyó utolsó náci csapatok.

- El lehetett volna oltani a tüzet?

- Nem, mert a nácik tủz alatt tartották a behatoló szovjet csapatokat.

- Mi értelme volt az ősi város megsemmisítésének?

- A felperzselt föld taktikája hozzátartozott a hitleri hadviseléshez. (Ruffy, 1961. 46-47.)

Ahogy kitünik az idézett részletből, Ruffy lengyel beszélőpartnere Gdańsk elpusztításáért a németeket hibáztatja.

Pethő Tibor, aki az útleírásában elég részletesen megismerteti a magyar olvasóval Gdańsk történetét, csak ennyit ír a város 1945-ös évi elpusztításának körülményeiröl:

1945 márciusában érkeztek Gdańsk alá a szovjet csapatok és az I. Lengyel Pácélos Hadosztály katonái. Az ostrom hat hétig tartott, a németek kivonulásakor tüz ütött ki a városban. ${ }^{33}$ (Pethő, 1956. 128.)

A szerző továbbá hangsúlyozza, hogy Gdańsk szinte teljes megsemmisítése nagy veszteség volt az európai kultúra számára: „A tüz és láng martaléka lett tíz évszázad szorgos nemzedékeinek minden munkája, az európai kultúra számos felbecsülhetetlen értékü müemléke" (Pethö, 1956. 128.) - olvassuk A Kárpátoktól a Balti-tengerig lapjain.

Arról, milyenek voltak a pusztítás méretei, vagy pontosabban: hogyan nézett ki a város közvetlenül a harcok befejezése után, föleg Ruffy Péter Varsói hajnaljában olvashatunk. Meg kell jegyezni, hogy sem Ruffy, sem a többi két szerző nem láthatta ezeket a pusztításokat teljes egészükben. A tengerparti látogatásuk alatt a város háborúban elpusztított, legfontosabb, legértékesebb épületeinek egy részét már sikerült helyreállítaniuk az újjáépítőknek, a többi rekonstrukciója azonban még folyamatban volt.

Ruffyt a pusztítás méreteivel a fentebb említett „Ticzner” nevü újságírón kívül egy másik lengyel, „egy gdański pártmunkás” is megismertette. Mindkét beszélgetés bekerült az útirajz szövegébe. A magyar szerző azonban nemcsak idézi a két lengyel visszaemlékezését, hanem a hallottak alapján, a rá jellemző stílussal, szinte posztapokaliptikus képet fest a megsemmisített, kihalt városról:

Gdańsk nem romváros volt, hanem egy emeletnyi magas, összefüggő hamutenger. A törmelék az utcákat is beborította. Mintha földrengés pusztított volna. Por és hamu volt a világhírü város helyén. A törmelékeken itt-ott lezuhant repülögépek roncsai ágaskodtak, a kikötőben az ide menekült, elhagyott náci tengeralattjárók rozsdás oldala látszott ki a vízböl. (Ruffy, 1961. 49.)

${ }^{32}$ Minden valószínűség szerint Henryk Tycner lengyel újságíróról van szó.

${ }^{33}$ Kiemelés: M. G. 
Pethő Tibor csak annyit jegyez meg a pusztítás méreteit illetően, hogy Gdańsk a felszabadulás pillanatában ,alig volt egyéb, mint üszkös rom” (Pethő, 1956. 128.). Somlyó György pedig „Gdansk rommá lőtt rakpartjairól” (Somlyó, 1954. 81.) ír, amelyeket ahogy kitünik az útleírása szövegéböl - személyesen látott a tengerparti látogatása alatt. De e kisebb észrevételén kívül Somlyó másképpen is bemutatja Gdańsk háborús történetét, valamint a háború utáni újjáépítését. A gdański városháza termeiben egykor található két remekmívü festmény perspektívájából nézi Gdańsk történetének e két fejezetét. ${ }^{34}$ Az első festmény címe A templom épitése (lengyelül: Budowa światyni), Anton Möller müve, s 1602-ben készült (ma nem a régi városházában, hanem a gdański Nemzeti Múzeum gyüjteményében található). A címének megfelelően a festmény egy hatalmas templom építését ábrázolja, láthatjuk rajta a magas állványokon dolgozó munkásokat. Somlyó György szemében ez a 17. századi reneszánsz festmény jól tükrözi Gdańsk második világháború befejezése utáni állapotát:

Gdanskban járva még külön távlatot kapott számomra Anton Moeller képe. Az akkor felépített falak ma alaktalan törmelékként hevernek szerteszét, vörösen, mint a feltépett nyers hús. $\mathrm{S}$ most emelkednek újra az állványok, hogy mint négyszáz évvel ezelőtt, újra a magasba szökkenhessenek mellettük a székesegyház falai. (Somlyó, 1954. 43.)

Somlyó útleírásának e sorai sajátos irodalmi utalásként hatnak Gdańsk 1945. évi elpusztítására és a háború utáni újjáépítésére.

A képen ábrázolt épülő templom elsősorban a Gdańsk fő templomának, a belvárosban levő híres Mária-templomnak a sorsát juttatja a szerző eszébe. A város egyik szimbólumának tekintett Mária-templom 1945 márciusában szinte teljesen elpusztult, a háború után 1946 és 1950 között végeztek rajta újjáépítési munkálatokat. Tágabb értelemben Somlyónak a Möller-festmény körüli elmélkedései Gdańsk elpusztított épületeinek összességére is vonatkoztathatók. Az, ami néhány évszázaddal korábban épült fel, a háborús pusztítások következtében romokban hever; a szétrombolt falak vörös téglái úgy néznek ki, mint a nyers hús, és ezáltal a háború halálosan emberi áldozataira is emlékeztethetnek. A Visztula sellöje e részletének a vezérgondolata megegyezik Pethő Tibor fentebb idézett szavaival: „A tüz és láng martaléka lett tíz évszázad szorgos nemzedékeinek minden munkája, az európai kultúra számos felbecsülhetetlen értékü müemléke" (Pethö, 1956. 128.).

Anton Möller 17. századi festménye a szerző szemében Gdańsk újjáépítését is jól tükrözi; az ötvenes évek első fele Gdańskjának látképében megint jelen vannak, „emelkednek újra" az állványok (úgy, mint a régi időkben), megint számos építkezési munkálat folyik.

A Somlyó György által említett másik képnek a címe - szó szerinti fordításban Gdańsk Apoteózisa, Gdańsk Lengyelországgal való összeköttetésének apoteózisa vagy A gdański kereskedelem apoteózisa (lengyelül: Apoteoza Gdańska, Apoteoza łaczności Gdańska z Polska vagy Apoteoza handlu gdańskiego; a magyar író a következő címét adja: A gdanski kereskedelem virágzásának allegóriája), 1608-ban készült, Izaak van den Blocke flamand származású gdański festő alkotása.

A festmény Gdańsk idealista vízióját állítja a néző szeme elé. Gdańsk tökéletes, az Isten által kiválasztott városként jelenik meg. A kép középpontjában a gdański Városi Tanácsot jelképező diadalív, a csúcsán pedig Gdańsk jellegzetes látképe látható a városházával együtt, amelynek tornyát Istennek a felhőkből kinyúló keze tartja. Ez annak

34 Vagyis a város háborús történetét és a háború utáni újjáépítését. 
Marcin Grad: Három magyar a Balti-tengerné

jelképe, hogy az Isten fejlődést és jólétet biztosít a városnak (a Városi Tanács közvetítésével). Van den Blocke festményének alsó részében a gdański kereskedő kezet fog a lengyel nemessel, a megegyezés jeléül (Śliwiński, 2012. 43-44.).

A festmény Gdańsknak nemcsak a „tökélességét" fejezi ki, hanem a régi Lengyelország életében betöltött jelentőségére és kiváltságos helyére is utal (van den Blocke idejében Gdańsk a lengyel államhoz tartozott).

Somlyó leírja a képen ábrázolt jelenetet és megmagyarázza a jelentését:

A hatalmas méretű képen Jehovának a felhökböl kinyúló keze tartja a városháza arany tornyát, a Visztula több ágra szakadozva ömlik a tengerbe, deltájában nagy négyszögü uszályok fuvarozzák a búzát, a téren ácsorgó, társalgó, üzletelő polgárok között az előtérben egy föúr szívélyesen kezetráz egy köznemessel. S a polgárok közt elvegyülve ott látjuk szárnyas bokával settenkedni a polgárság vezérlő istenét, az ifjú Hermést. A kép elképzelésében a világon - vagyis Gdanskban - mindennek megvan a maga tévedhetetlenül biztos helye. Három vallás békés kézfogása mindent a legmegtámadhatatlanabb rendben tart a világon. (Somlyó, 1954. 43.)

Izaak van den Blocke képe, hasonlóképpen, mint Anton Möller festménye, a legújabb történelemre vonatkozó reflexióra készteti Somlyót:
A magyar író szerint Gdańsk történetében paradoxon rejlik: ugyanabban a városban, amely a régi Lengyelország „gyöngyszeme" volt, amely hires volt a gazdagságáról és a szépségéról, néhány évszázaddal késóbb kitört a második világháború, amely pusztítást hozott nemcsak magának a városnak, hanem szinte az egész világnak. Somlyó szerint ezt a katasztrófát „az isten tenyerében oly nyugodtan csücsüló polgárságnak egyenes utódai" készitették „maguknak és az egész emberiségnek”. Ez az egyébként költói jellegú mondat a németekre vonatkozik, elsósorban a gdański (danzigi) németekre, akik ugyan önmaguktól nem robbantották ki a háborút, de Hitler politikáját támogatták. Somlyó e megállapítása beleíródik a háború utáni németellenes diszkurzusba.

A történelem sokszor oly kaján és tragikus dialektikája úgy akarta, hogy háromszázharminc esztendővel e kép megalkotása után éppen ebben az isteni kezek s a fejlődő tőke által oly biztosan tartott városban robbanjon ki a világtörténelem eddigi legiszonyúbb ,rendetlensége”, s éppen ezt a várost rombolja le elsőnek az az esztelen pusztítás, amelyet ugyanennek az isten tenyerében oly nyugodtan csücsülö polgárságnak egyenes utódai készítettek maguknak és az egész emberiségnek. (Somlyó, 1954. 43-44.)

A magyar író szerint Gdańsk történetében paradoxon rejlik: ugyanabban a városban, amely a régi Lengyelország ,gyöngyszeme” volt, amely híres volt a gazdagságáról és a szépségéről, néhány évszázaddal később kitört a második világháború, amely pusztítást hozott nemcsak magának a városnak, hanem szinte az egész világnak. Somlyó szerint ezt a katasztrófát „az isten tenyerében oly nyugodtan csücsülő polgárságnak egyenes utódai” 
készítették „maguknak és az egész emberiségnek”. Ez az egyébként költői jellegű mondat a németekre vonatkozik, elsősorban a gdański (danzigi) németekre, akik ugyan önmaguktól nem robbantották ki a háborút, de Hitler politikáját támogatták. Somlyó e megállapítása beleíródik a háború utáni németellenes diszkurzusba.

A fentiekben már esett szó Gdańsknak a második világháború utáni újjáépítéséről; a három szerző közül Ruffy és Pethő ír többet a város újjáépítéséről, pontosabban: a régi Gdańsk újjáépítéséröl és az új város kiépítéséröl.

Ruffy Péter, aki egyébként a Varsói hajnalban különös lelkesedéssel mutatta be a magyar olvasóknak egész Lengyelország a háború utáni újjáépítését, kiemeli Gdańsknak az élénkségét, hiszen nem egész tizenöt éven belül épült fel a város a háborús pusztításokból:

Végigjárjuk a várost, csillogó körutak, a Hansa-kort idéző ódon, vöröstéglás épületek, a régi cukrászdák hangulatát idéző kis cukorházak, szeszélyes girlandokkal, aranycsipkékkel... Vén, szakállas patríciusok palotái a XX. század közepén! A Diák Klubban vad tánc folyik; az egyetem nemzetközi diákszállójában ghanai, amerikai, szovjet, svéd, magyar diákokat találunk. Megnézzük Gdynia kikötőjében a „Báthory” óceánjáró hajót, s végül meglátogatjuk Gdańsk nehéziparának büszkeségét, a világhírü hajógyárat. (Ruffy, 1961. 52.)

Így tekint az újjáépített Gdańskra a magyar szerző, egy kicsit propagandisztikusnak nevezhető irodalmi képeslapot alkotva róla. Gdańsk a Varsói hajnal narrációjában a régi és az új városa. Ez egyébként nemcsak Gdańskra, hanem az egész országra vonatkozik. Ruffy többször nagy lelkesedéssel mutat rá a lengyel újjáépítés e sajátos paradoxonára, illetve kettősségére, arra tudniillik, hogy a 20. század közepén régi házak, paloták stb., a „régi világba” tartozó épületek újra megjelennek Lengyelország látképében.

A szocializmus kora várakat, egykori királyi palotákat épít, romba dőlt palotákat gót ablakfonatokkal vagy reneszánsz támpillérekkel, középkori kapuvasalásokkal. [...] Varsóban egy időben épült a Szovjetunió hatalmas ajándéka, a hatalmas arányú felhőkarcoló, a kultúra palotája és az Óváros fantasztikus fogazatú, vasrácsos, középkori és reneszánsz Ópiaca. A lengyel városban egy időben születnek középkori városrészek és tizennégy emeletes bérpaloták. Egyszerre építik a régen meghalt patríciusok házait és a munkásosztály magasba törő, napfényes otthonait. Egy időben születik a felvonó és a középkori freskó; a felhőharcoló és a varsói Ópiac tündéri házain látható dombormü, amely középkori családok foglalkozásának különböző jelvényeit ábrázolja. [...] (Ruffy, 1961. 18-19.).

Gdańsk újjáépítésének méretei ámulatba ejtik Ruffyt: kiutazáskor, a vonaton ülve, visszanéz „,a világháború kitörésének fényben fürdő, reneszánsz ragyogásban szikrázó városára”, s némi stilizált hitetlenséggel teszi fel a kérdést: „És az alig tizenöt éve emeletnyi magas, összefüggő hamutenger volt?...” (Ruffy, 1961. 53.). A magyar újságíró a Gdańskról szóló fejezetet pátosszal teli fohásszal fejezi be, amely sokat elárul a politikai nézeteiről (Ruffy a Varsói hajnal lapjain a szocializmus igazi és őszinte rajongójának tünik). Az említett fohász a nyíltan propagandisztikus, a szocialista rendszert glorifikáló tendencia jegyeit mutatja (úgy, mint az egész útleírás): „Munkások, ti hősök! Kommunisták, ti héroszok!” (Ruffy, 1961. 53.)

Pethő Tibor, aki a könyvében elég hosszú, bedekkerszerü leírását adja Gdańsk óvárosának, kiemelve az ottani épületek müvészeti szépségét, ír „az új Gdańskról” és ennek az építészeti stílusáról is: 
A régi városon túl épül az új Gdańsk. Hatalmas lakónegyedek épülnek az egyre nagyobb számú ipari munkásság számára. Ezek az új házak azonban egyáltalán nem ütnek el a hagyományos gdański építkezési stílusról. Mintha csak az Ulica Długa házainak új modern változatait látnánk. (Pethő, 1956. 137.)

Az idézett részletben a szerző Gdańsk újonnan épített szocialista realista stílusú lakótelepeire utal, minden valószínüség szerint elsősorban a Grunwaldzka Dzielnica Mieszkaniowa nevü lakótelepre, amely építésének nagyszabású tervét egyébként nem sikerült teljes egészében megvalósítani (Orzechowska-Pawlik, 2017. 59-70.; Perkowski, 2013. 269.). Pethő szerint a nagy építkezési munkálatok az ötvenes évek közepén Gdańsk mindennapi életének fontos részét képezték, ami már a városba való megérkezés első pillanataiban is érezhető volt:

Megilletődve szálltunk ki Európának azon a földrajzi pontján, ahol a második világháború első puskalövése eldördült. A vihar, amely ebböl az Aeolus-barlangból tört a világra, már régen elcsitult.

A tenger felől hüs, sós szellő kavarja szemünkbe a port, mert hiszen a nagy építkezések miatt poros az egész város. ${ }^{35}$ (Pethő, 1956. 124.)

Ahogy már megjegyeztünk a fentiekben, Pethő Tibor végigjárta a régi Gdańskot, és bemutatja a magyar olvasónak a város legszebb, történelmi jellegü épületeit. A szerző ugyanazt az utat teszi meg, amely manapság is jellemzi a Gdańskba érkező turisták többségének programját. Gdańsk óvárosának e bemutatása, bár irodalmi értéke van, továbbá érdekes és vonzó lehet az olvasó számára, alapvetően nem különbözik jelentősen az útikönyvszerü leírásoktól, ezért részletesen nem fogjuk tárgyalni e tanulmányban. Érdemes ugyanakkor megjegyezni, hogy az egyik óvárosi ház falán látható, kőbe vésett, két részből álló latin nyelvű felirat vonta magára a szerző figyelmét. ${ }^{36}$ A felirat szövege egy közismert latin szentencia: „navigare necesse est, vivere non est necesse” 37 , aminek magyar

35 Kiemelés: M. G.

36 Pethő tévesen állítja, hogy a felirat a Magas Kapu falán található.

37 A felirat pontos szövege: (az első része) „Navigare necessum est” és (a második része) „Vivere non necesse”.
Ahogy már megjegyeztünk a fentiekben, Pethó Tibor végigtatja a magyar olvasónak a város legszebb, történelmi jellegú épületeit. A szerzó ugyanazt az utat teszi meg, amely manapság is jellemzi a Gdańskba érkezó turisták többségének programját. Gdańsk óvárosának e bemutatása, bár irodalmi értéke van, továbbá érdekes és vonzó lehet az olvasó

számára, alapvetóen nem különbözik jelentốsen az útikönyvszerú leírásoktól, ezért részletesen nem fogjuk tárgyalni e tanulmányban. Érdemes ugyanakkor megjegyezni, hogy az egyik óvárosi ház falán látható, kóbe vésett, két részból álló latin nyelvú felirat vonta magára a szerzó figyelmét. A felirat szövege egy közismert

latin szentencia: „navigare necesse est, vivere non est necesse", aminek magyar jelentése „Hajózni muszáj, élni nem szükséges". járta a régi Gdańskot, és bemu- 
jelentése „Hajózni muszáj, élni nem szükséges”. ${ }^{38}$ E felirat sajátos utalás Gdańsknak a tengerrel való kapcsolatára. Pethő - akire hatással volt a város nagyszabású újjáépítése azt állítja, hogy a háború utáni Gdańskhoz a kőbe vésett latin szentencia újabb változata illene: „Nemcsak hajózni szükséges, hanem építkezni is” (Pethő, 1956. 137.).

\section{Összegzés}

A Balti-tengernek és Gdańsknak mindhárom útleírásból kirajzolódó összképe „tartalmilag" alapvetően egységes. Ez elsősorban Pethő Tibor és Ruffy Péter tenger- és Gdańsk-képére vonatkozik. Ahogy már említettük a bevezetésben, mind a két szerző a Balti-tenger és Gdańsk egybefüggő képét alkotja meg; Somlyó György pedig nem alkot riportszerü hosszabb leírásokat a Balti-tengerről vagy a tengerparti városokról; egyes mozzanatokat, tárgyakat, eseményeket, a tengeri vagy tengerparti tájképnek, Gdynia vagy Gdańsk életének egyes ,elemeit” választja ki és teszi meg azokat filozófiai, politikai, történelmi (stb.) elmélkedéseinek kiindulópontjává. De mégis ezeken a kiválasztott „,kisebb” elemeken keresztül a Balti-tengernek vagy Gdańsknak sajátos képe rajzolódik ki előttünk - a szerző például Anton Möller és Izaak van den Blocke festménye perspektívájából láttatja a város háborús elpusztítását és újjáépítését.

Ami a Balti-tenger képét illeti, Pethő Tibor és Ruffy Péter hangsúlyozzák e tenger fontos szerepét az „új”, szocialista Lengyelország életében. Jól kifejezik ezt Ruffy már idézett szavai: „Lengyelország tengeri hatalommá vált” (Ruffy, 1961. 124.). Mind a három útleírásban (legkevésbé viszont Somlyónál) Gdańsk háborús története, valamint Gdańsknak a háború utáni (sikeres) újjáépítése kerül a figyelem középpontjába.

Bár a szóban forgó útleírások nem mentesek a korabeli „hivatalos” propaganda befolyásától, s teljesen belesimulnak a háború utáni lengyel történelmi és politikai diskurzusba, mégis az ötvenes-hatvanas években lehetővé tették, hogy a magyar olvasó közelebbről belelásson a lengyel történelembe vagy Lengyelország kultúrájába és mindennapi életébe.

\section{Irodalom}

Béládi Miklós \& Rónay László (1990, szerk.). A magyar irodalom története 1945-1975. 3, A próza és a dráma. 2. kötet. Budapest: Akadémiai Kiadó 1990. (Ruffy Péter életrajza)

Bilska, A. \& mtsai (2018). Polska gospodarka morska 1918-2018. Szczecin: Urząd Statystyczny w Szczecinie. Ośrodek Statystki Morskiej

Ćurković-Major Franciska (2002). Zágráb képe Fejtö Ferenc Érzelemes utazás címü regényében. Tiszatáj, október, 79-80.

Dávid Gyula (2002, főszerk.). Romániai magyar irodalmi lexikon. IV. kötet. Bukarest-Kolozsvár, Erdélyi Múzeum-Egyesület - Kriterion Könyvkiadó. (Ruffy Pter életrajza)

Drzycimski, A. (1990). Major Henryk Sucharski. Zakład Narodowy im. Wrocław: Ossolińskich.
Drzycimski, A. (2009). Westerplatte 1939: historia i legenda. Przed szturmem. Gdańsk: Wydawnictwo Słowo/Obraz Terytoria.

Dymarski, Z. (2017, szerk.). Człowiek $i$ miasto. Gdańszczanie między stara a nowa tożsamościa. Gdańsk: Wydawnictwo Uniwersytetu Gdańskiego.

F. Almási Éva (é. n. 1). Kortárs magyar irók 1945-1997. Pethő Tibor életrajza. http://mek.oszk. hu/00000/00019/html/p/i010392.htm Utolsó letöltés: 2019. 09. 30.

F. Almási Éva (é. n. 2). Kortárs magyar irók 1945-1997. Ruffy Péter életrajza. http://mek.oszk. hu/00000/00019/html/r/i011136.htm Utolsó letöltés: 2019. 09. 30.

Kardas, M. (2011). Okupacja hitlerowska Helu. Wybrane aspekty. Zeszyty Naukowe Akademii Marynarki Wojennej, 2, 165-186.

38 Pethő fordításában: „Hajózni szükséges, élni nem szükséges”. 
Orzechowska-Pawlik, K. (2017). Próba stworzenia socjalistycznego Gdańska - Śródmieście oraz Grunwaldzka Dzielnica Mieszkaniowa. In: Dymarski, Z. (2017, szerk.). Człowiek i miasto. Gdańszczanie między stara a nowa tożsamością. Gdańsk: Wydawnictwo Uniwersytetu Gdańskiego.

Perkowski, P. (2013). Gdańsk - miasto od nowa. Ksztaltowanie spoleczeństwa $i$ warunki bytowe $w$ latach 1945-1970. Gdańsk: Wydawnictwo Słowo/ Obraz Terytoria.

Pethő Tibor (1956). A Kárpátoktól a Balti-tengerig. Budapest: Szikra Könyvkiadó.

Ruffy Péter (1961). Varsói hajnal. Budapest: Kossuth Könyvkiadó.

Śliwiński, B. \& mtsai (2012, szerk.). Encyklopedia Gdańska. Gdańsk: Fundacja Gdańska.

Somlyó György (1954). A Visztula sellöje. Lengyelországi útinapló. Budapest: Szépirodalmi Kiadó.

Szokolay Katalin (1996). Lengyelország története. Budapest: Balassi Kiadó.
Tamás István (1961). „Varsói hajnal”. Ruffy Péter könyve. Magyar Nemzet, 45, 7.

Tuliszka, J. (2011). Westerplatte 1926-1939. Toruń: Wydawnictwo Adam Marszałek.

Wańkowicz, M. (1990). Westerplatte. Warszawa: Instytut Wydawniczy „Pax”.

Wąs, M. (2012). Zburzenie Gdańska (Interjú dr. Jan Daniluk történésszel). Ale Historia: tygodnik historyczny, 26(3-4).

Wasilewski Krzysztof (2013). Legenda Westerplatte to mit. Przeglad, 02. 11., https://www.tygodnikprzeglad.pl/legenda-westerplatte-mit/ Utolsó letöltés: 2019. 09. 30 .

Wroński, S. \& Zwolakowa, M. (1966, szerk.). Polska: 1944-1965, T.2 (1956-1965). Warszawa: Książka i Wiedza.

Zsoldos Sándor (é. n.). Somlyó György életrajza. Digitális Irodalmi Akadémia, https://pim.hu/hu/dia/ dia-tagjai/somlyo-gyorgy\#eletrajz Utolsó letöltés: 2019. 09. 30.

\begin{abstract}
Absztrakt
A második világháború utáni korszakban a magyar írók és újságírók Lengyelország iránti érdeklődésének jó bizonyítéka néhány lengyelországi útirajz vagy riportkönyv: Visztula sellöje Somlyó Györgytől (1954), A Kárpátoktól a Balti-tengerig Pethő Tibor tollából (1956), valamint Varsói hajnal. Lengyelországi útiélmények Ruffy Pétertől (1961). A jelen tanulmány célja bemutatni, hogy a fentebb említett három magyar szerző hogyan látja a Balti-tengert és ennek az új szocialista Lengyelország életében betöltött szerepét, milyen hatást gyakoroltak rájuk a lengyel tengerparti városok, elsősorban a gazdag és viharos múltú Gdańsk.
\end{abstract}

